RESEARCH REPORT

\title{
Understanding the dimensions of socioeconomic status that influence toddlers' health: unique impact of lack of money for basic needs in Quebec's birth cohort
}

\author{
Louise Séguin, Qian Xu, Lise Gauvin, Maria-Victoria Zunzunegui, Louise Potvin, Katherine \\ L Frohlich
}

J Epidemiol Community Health 2005;59:42-48. doi: 10.1136/jech.2004.020438 See end of article for
authors' affiliations

Correspondence to:

$\operatorname{Dr} L$ Séguin, Département de médecine sociale et préventive, Université de Montréal, CP 6128, Succursale Centre-Ville, Montréal, Québec, Canada H3C 3 J7; Lovise. Seguin@umontreal.ca

Accepted for publication 30 July 2004

\begin{abstract}
Study objectives: To examine the unique impact of financial difficulties as measured by a lack of money for basic needs on the occurrence of health problems between the ages of 17 and 29 months, controlling for mother's level of education and neonatal health problems.

Design and participants: Analyses were performed on the 29 month data of the Quebec longitudinal study of child development. This longitudinal study followed up a birth cohort annually. Interviews were conducted in the home with the mother in $98.8 \%$ of cases. This information was supplemented with data from birth records. At 29 months, the response rate was $94.2 \%$ of the initial sample $(n=1946)$. The main outcome measures were mothers' report of acute health problems, asthma episodes, and hospitalisation as well as growth delay and a composite index of health problems (acute problems, asthma attack, growth delay).

Main results: Children raised in a family experiencing a serious lack of money for basic needs during the preceding year were more likely to be reported by their mothers as presenting acute health problems, a growth delay, two or more health problems, and to have been hospitalised for the first time within the past few months as compared with babies living in a family not experiencing a lack of money for basic needs regardless of the mother's level of education and of neonatal health problems.

Conclusion: Financial difficulties as measured by a lack of money for basic needs have a significant and unique impact on toddlers' health.
\end{abstract}

$\mathrm{T}$ he relation between family poverty and children's health is well known. ${ }^{1-6}$ However, few population level studies have examined the morbidity of toddlers in relation to parents' poverty. ${ }^{7-9}$ Epidemiological studies include children in the 0 to 17 year age range..$^{1-6-14}$ Various studies have examined specific health problems that occur more frequently in poor children. ${ }^{15-18}$ Some authors have also emphasised that children from poor families may accumulate several health problems at once. ${ }^{1}$ In studies dealing with young children's health, researchers have often focused on consequences of low birth weight or premature birth but without consideration to the family's socioeconomic status. ${ }^{19-22}$ Although extant research shows a relation between socioeconomic status and child health, there are still unresolved issues pertaining to which aspects of socioeconomic status are important to young children's health. This study attempts to disentangle some of these issues.

Child poverty is characterised by several inter-related features including lack of material resources, low level of education in the mother, and younger parents. The relative influence of each of these features on the child's health and the role of relative deprivation compared with absolute lack of material resources is currently the subject of debate. ${ }^{23-32}$ According to some, lack of parental skills resulting from lower maternal education better explains disparities in children's health than lack of material resources resulting from low family income. ${ }^{26} 33-35$ Moreover, neonatal health problems and mother's health habits are sometimes viewed as mediators of the relation between poverty and health of children. Premature births and intrauterine growth delays are more frequent among poor children. Children from poor families are less often breast $\mathrm{fed}^{36}$ and more often have parents who smoke. ${ }^{33}$ Given these influences, it is not clear whether or not financial difficulties play a unique part in undermining the child's health.

Measuring poverty is as challenging as defining it. ${ }^{2837}$ Annual family income, from which low income thresholds are established, provides information on resources linked to income over the past year but does not incorporate information about other resources (social or material) on which a family may count in difficult times. An alternative to using family income as an indicator of material strain consists of assessing a lack of money for basic needs. This measure provides a combined indicator of financial difficulties and lack of resources that might better operationalise the notion of financial difficulties that might result in child health problems.

It is noteworthy to mention that although Quebec toddlers are likely to share much in common with American or British toddlers, they benefit from universal health insurance coverage and universal day care programmes that may result in differing cross national patterns. This study therefore examined the links between one indicator of financial difficulties ("a lack of money for basic needs") and several indicators of health while controlling for maternal education and age, the child's previous health status, neonatal health problems, his/her characteristics, and other factors associated with each of the health indicators in a cohort of children aged 29 months that is representative of singleton births in the province of Quebec. The goal is to ascertain the unique effect of serious financial difficulties ("a lack of money for basic need"). Children from the cohort have been tracked annually since their birth in the context of the Quebec longitudinal study of child development. Filling in the gap in knowledge regarding the role of the lack of material resources is important in establishing relevant social policies for child health. 
Table 1 Distribution of 2.5 year old children in Quebec longitudinal study of child development (QLSCD 1998-2002) according to their characteristics, their neonatal health problems, and their environment during the past 12 months $(n=1946)$

\begin{tabular}{|c|c|c|}
\hline & $\%$ & $95 \% \mathrm{Cl}$ \\
\hline \multicolumn{3}{|l|}{ Baby's sex } \\
\hline Female & 49.4 & 47.1 to 51.8 \\
\hline Male & 50.6 & 48.2 to 52.9 \\
\hline \multicolumn{3}{|l|}{ Birth rank } \\
\hline lst & 44.3 & 41.9 to 46.6 \\
\hline 2nd & 39.1 & 36.9 to 41.4 \\
\hline 3rd or more & 16.6 & 14.9 to 18.3 \\
\hline \multicolumn{3}{|l|}{ Congenital abnormality } \\
\hline No & 92.0 & 90.7 to 93.3 \\
\hline Yes & 8.0 & 6.7 to 9.3 \\
\hline \multicolumn{3}{|l|}{ Small for gestational age $<10$ th centile* } \\
\hline No & 93.5 & 92.3 to 94.7 \\
\hline Yes & 6.5 & 5.3 to 7.7 \\
\hline \multicolumn{3}{|l|}{ Premature birth ( $<37$ weeks) } \\
\hline No & 93.5 & 92.1 to 94.8 \\
\hline Yes & 6.5 & 5.2 to 7.9 \\
\hline \multicolumn{3}{|l|}{ Parents' smoking (past 12 months) } \\
\hline No parent smoking & 65.7 & 63.4 to 68.0 \\
\hline One parent who smokes in the home & 21.3 & 19.2 to 23.3 \\
\hline Two parents who smoke in the home & 13.0 & 11.5 to 14.7 \\
\hline \multicolumn{3}{|l|}{ Length of exclusive breast feeding } \\
\hline Never breast fed & 28.2 & 26.1 to 30.3 \\
\hline Breast fed since birth, but not exclusively & 5.8 & 4.6 to 6.9 \\
\hline 1 day to 4 weeks & 18.9 & 17.0 to 20.8 \\
\hline 5-9 weeks & 20.1 & 18.2 to 21.9 \\
\hline 10-14 weeks & 10.5 & 9.2 to 11.9 \\
\hline 15 weeks or longer & 16.6 & 14.9 to 18.3 \\
\hline \multicolumn{3}{|l|}{ Type of child care (past 12 months) } \\
\hline At home with the mother or another person & 49.6 & 47.2 to 51.9 \\
\hline Outside of the home & 32.4 & 30.2 to 34.5 \\
\hline At a day care centre & 16.8 & 15.1 to 18.5 \\
\hline Variable child care & $1.2 \dagger$ & 0.8 to 1.8 \\
\hline \multicolumn{3}{|c|}{$\begin{array}{l}\text { *Small for gestational age ( }<10 \text { th centile) according to the Kramer curve } 2001 \text {. †Coefficient of variation betweer } \\
15 \% \text { and } 25 \% \text {; data should be interpreted with caution. The coefficient of variation is a measure of dispersion of the } \\
\text { data around the mean. It is the ratio of the standard deviation to the mean of a distribution. It does not have an } \\
\text { metric and is usually expressed in percentage. Large coefficients of variation indicate a large dispersion of datc } \\
\text { around the mean and a loss of accuracy of the mean estimate (BMDP statistical soffware, Los Angeles, 1990). }\end{array}$} \\
\hline
\end{tabular}

\section{METHODS}

Analyses were carried out on data from Quebec's longitudinal study of child development (QLSCD 1998-2002) conducted by Santé Québec, a division of the Institut de la statistique du Québec (ISQ) when children were aged on average 29 months (27 to 31 months). This study annually tracks a representative sample of Quebec children. The initial sample was recruited from the Quebec birth registry when babies were about 5 months old and is representative of singleton births in Quebec in 1997-1998, excluding babies born to mothers living in Northern Quebec, in Cree and Inuit territories as well as on First Nations reservations $(2 \%) .^{38}$ All singleton births in the included territories were eligible except births of unknown gestational age and premature babies born before 24 gestational weeks.

The research was approved by the human research ethics committee of the Faculty of Medicine of Université de Montréal. Two data sources were used: data on neonatal health problems, weight and height measurements at birth, and mother's height were drawn from hospital birth records. Other data came from interviews conducted in the home after having obtained written consent from parents of the babies. Questions concerning the mother's and child's characteristics, and child health problems were addressed to the mother in $98.8 \%$ of cases. Child height was measured by the interviewer following a standardised method at 29 months.

Dependent variables were (1) - mothers' report of: (a)presence, during the previous three months, of at least one acute health problems (respiratory tract infections, otitis media, gastroenteritis, or other infections), (b)-occurrence of at least one asthma episode in the past 12 months, (c)hospitalisations for one or more nights during the previous 12 months, (2)-occurrence of a growth delay (height under the 10th centile of $\mathrm{Z}$ scores according to the CDC growth curve, 2000), ${ }^{39}$ (3)-composite index of health problems at 29 months (presence of $0-1$ versus $2-3$ of the following problems: acute problems, asthma episode, growth delay).

The main independent variable was a score resulting from an ordinal scale indicating occurrence of a lack of money for basic needs (unable to pay bills for rent, heat, electricity, prescription drugs, children's clothing, and other necessities over the past 12 months) and its degree of severity as reported by the mother. Scores varied from 0 to 12 and were re-categorised following an analysis of agreement: score $0=$ never been short of money for basic needs; score 1-2 indicating a lack of money for basic needs, and score 3 and over indicating a serious lack of money for basic needs. The undimensional scale had a Cronbach $\alpha$ of 0.79 and was correlated with level of family income sufficiency defined by Statistic Canada. The scale also correlated with chronic poverty defined as having had a low family income at each of the three study periods in 1998, 1999, and 2000. A prior validation study of the scale also showed a Cronbach $\alpha$ of 0.79 (unpublished data).

Main control variables were the mother's level of education ( 1-partial or completed college-university studies; 2-high school or trade school diploma; 3-no high school diploma) and neonatal health problems (preterm birth, small for gestational age, congenital abnormality). Fathers' level of education and occupation were not taken into account because of too many missing data points. Other control 
Table 2 Distribution of 2.5 year old children in Quebec longitudinal study of child development (QLSCD 1998-2002) according to the mother's characteristics ( $n=1946$ )

\begin{tabular}{|c|c|c|}
\hline Mother's characteristics & $\%$ & $95 \% \mathrm{Cl}$ \\
\hline \multicolumn{3}{|l|}{ Mother's age when the child was 5 months old } \\
\hline under 20 & 3.3 & 2.4 to 4.3 \\
\hline 20 to 34 & 82.4 & 80.6 to 84.2 \\
\hline 35 or more & 14.3 & 12.6 to 16.1 \\
\hline \multicolumn{3}{|l|}{ Mother's education when the child was 5 months old } \\
\hline Partial or completed college or university studies & 60.5 & 58.1 to 62.9 \\
\hline High school or vocational or trade school diploma & 22.0 & 20.0 to 24.0 \\
\hline No high school diploma & 17.5 & 15.6 to 19.4 \\
\hline \multicolumn{3}{|l|}{ Presence of a partner when the child is 2.5 years } \\
\hline Lives with a partner & 87.3 & 85.5 to 89.0 \\
\hline Lives without a partner & 12.7 & 11.0 to 14.5 \\
\hline \multicolumn{3}{|c|}{ Mother's immigration status when the child was 5 months old } \\
\hline Non-immigrant or European immigrant & 88.3 & 86.6 to 90.0 \\
\hline Non-European immigrant & 11.7 & 10.0 to 13.4 \\
\hline \multicolumn{3}{|c|}{ Mother's employment status when the child is 2.5 years } \\
\hline Homemaker & 44.0 & 41.7 to 46.3 \\
\hline Worker & 52.8 & 50.4 to 55.1 \\
\hline Student & $2.0^{*}$ & 1.4 to 2.8 \\
\hline Other & $1.2^{*}$ & 0.8 to 1.8 \\
\hline \multicolumn{3}{|l|}{ Mother's height } \\
\hline$<33$ rd centile & 25.9 & 23.8 to 28.0 \\
\hline 33-66th centile & 40.2 & 37.9 to 42.5 \\
\hline$>66$ th centile & 33.9 & 31.7 to 36.1 \\
\hline \multicolumn{3}{|c|}{$\begin{array}{l}\text { *Coefficient of variation between } 15 \% \text { and } 25 \% \text {; data should be interpreted with caution. The coefficient of } \\
\text { variation is a measure of dispersion of the data around the mean. It is the ratio of the standard deviation to the } \\
\text { mean of a distribution. It does not have any metric and is usually expressed in percentage. Large coefficients of } \\
\text { variation indicate a large dispersion of data around the mean and a loss of accuracy of the mean estimate (BMDP } \\
\text { Statistical Software, Los Angeles, 1990). }\end{array}$} \\
\hline
\end{tabular}

variables were child's health status at 17 months, child's age, sex, rank in the family, and duration of exclusive breastfeeding, mother's age, presence of a partner, immigration status, height, parents' smoking at home, type of day care in the past 12 months, and presence of a house pet at 5 months.

Analyses were conducted using sampling weights. The Direction Santé Québec developed sampling weights based on the sampling design and response rates (see: http://www. stat.gouv.qc.ca/publications/sante/bebe_v2nol_an.htm) to allow for accurate establishment of prevalence of health problems. After descriptive analyses, we estimated unadjusted odds ratios for each health outcome by lack of money for basic needs. Then, multivariate models of the relation between the score for lack of money and the presence of health problems using logistic regression were performed for each dependent variable controlling for confounding

Table 3 Distribution of 2.5 year olds in Quebec longitudinal study of child development (QLSCD 1998-2002) according to the score for lack of money for basic needs* $(n=1946)$

\begin{tabular}{|c|c|c|}
\hline & $\%$ & $95 \% \mathrm{Cl}$ \\
\hline \multicolumn{3}{|l|}{ Overall score for lack of money } \\
\hline Score $=0$ & 76.0 & 73.8 to 78.1 \\
\hline Score $=1-2$ & 14.5 & 12.7 to 16.3 \\
\hline Score $=3$ or more & 9.5 & 8.1 to 10.9 \\
\hline \multicolumn{3}{|l|}{ Lack of money to pay the rent or the mortgage* } \\
\hline Did not experience any lack of money & 87.9 & 86.3 to 89.5 \\
\hline A small lack of money & 8.7 & 7.4 to 10.1 \\
\hline A rather significant lack of money & $2.5 \dagger$ & 1.8 to 3.4 \\
\hline \multicolumn{2}{|l|}{ Lack of money to pay for the electricity, heating, or hot water* } & 0.5 to 1.4 \\
\hline Did not experience any lack of money & 85.7 & 83.9 to 87.4 \\
\hline A small lack of money & 10.7 & 9.2 to 12.2 \\
\hline A rather significant lack of money & 2.8 & 2.0 to 3.7 \\
\hline A very significant lack of money & $0.9 \ddagger$ & 0.5 to 1.5 \\
\hline \multicolumn{3}{|l|}{ Lack of money to buy prescription medications* } \\
\hline Did not experience any lack of money & 95.4 & 94.2 to 96.5 \\
\hline A small lack of money & 3.2 & 2.4 to 4.2 \\
\hline A rather significant lack of money & $0.9 \ddagger$ & 0.4 to 1.7 \\
\hline A very significant lack of money & $0.5 \ddagger$ & 0.2 to 1.0 \\
\hline \multicolumn{3}{|l|}{ Lack of money to pay for important expenses (clothing, transportation, etc)* } \\
\hline Did not experience any lack of money & 82.8 & 80.9 to 84.6 \\
\hline A small lack of money & 13.3 & 11.6 to 15.0 \\
\hline A rather significant lack of money & $3.0+$ & 2.2 to 4.1 \\
\hline A very significant lack of money & $1.0 \ddagger$ & 0.5 to 1.6 \\
\hline \multicolumn{3}{|c|}{$\begin{array}{l}\text { *During the past } 12 \text { months. †Coefficient of variation between } 15 \% \text { and } 25 \% \text {; interpret with caution. ‡Coefficient of } \\
\text { variation above } 25 \% \text {; imprecise estimation, provided only for indicative purposes. The coefficient of variation is a } \\
\text { measure of dispersion of the data around the mean. It is the ratio of the standard deviation to the mean of a } \\
\text { distribution. It does not have any metric and is usually expressed in percentage. Large coefficients of variation } \\
\text { indicate a large dispersion of data around the mean and a loss of accuracy of the mean estimate (BMDP Statistica } \\
\text { Software, Los Angeles, 1990). }\end{array}$} \\
\hline
\end{tabular}


Table 4 Population prevalence and unadjusted odds ratios and 95\% confidence intervals (CI) for health problems of 2.5 year old children in Quebec longitudinal study of child development (QLSCD 1998-2002) according to the score for lack of money for basic needs

\begin{tabular}{|c|c|c|c|c|c|}
\hline & $\begin{array}{l}\text { Acute health problem } \\
\text { ( } n=1946)\end{array}$ & $\begin{array}{l}\text { Asthma episode } \\
(n=1946)\end{array}$ & $\begin{array}{l}\text { Growth delay } \\
(n=1893)\end{array}$ & $\begin{array}{l}\text { Index of health } \\
\text { problems }=2-3 \ddagger \\
(n=1893)\end{array}$ & $\begin{array}{l}\text { Hospitalisation } \\
(n=1946)\end{array}$ \\
\hline $\begin{array}{l}\text { Population prevalence (\%) } \\
\text { Score for lack of money } \\
\text { Score }=0 \\
\text { Score }=1-2 \\
\text { Score }=3 \text { or more }\end{array}$ & $\begin{array}{l}61.2 \% \\
\text { OR }(95 \% \mathrm{CI}) \\
1 \\
1.1(0.9 \text { to } 1.4) \\
1.8(1.3 \text { to } 2.5)^{\text {** }}\end{array}$ & $\begin{array}{l}7.2 \% \\
\text { OR }(95 \% \mathrm{Cl}) \\
1 \\
1.2(0.8 \text { to } 1.9) \\
2.1(1.3 \text { to } 3.3)^{* *}\end{array}$ & $\begin{array}{l}9.6 \% \\
\text { OR }(95 \% \mathrm{Cl}) \\
1 \\
1.0(0.7 \text { to } 1.6) \\
1.9(1.2 \text { to } 2.9)^{\text {** }}\end{array}$ & $\begin{array}{l}11.2 \% \\
\text { OR }(95 \% \mathrm{CI}) \\
1 \\
1.2(0.8 \text { to } 1.8) \\
2.1(1.4 \text { to } 3.2)^{\star *}\end{array}$ & $\begin{array}{l}7.6 \% \\
\text { OR (95\% CI) } \\
1 \\
1.4(0.9 \text { to } 2.2) \\
2.3(1.5 \text { to } 3.7)^{\text {** }}\end{array}$ \\
\hline
\end{tabular}

variables. Firstly, we controlled for previous health problems and therefore explored the occurrence of health problems since age 17 months. We verified the assumption of homogeneity of slopes and observed no violations. Secondly, we did not control for previous health problems and therefore explored the predictive value of variables on health outcomes at 29 months.

Multivariate models were performed using SPSS logistic regression. All hypothesis tests and confidence intervals were re-calculated taking into account the design effect using SUDAAN software. Full models are available upon request.

\section{RESULTS}

Response rate at 29 months was $94.2 \%$. There was no difference in participation according to presence of an earlier health problem. After listwise deletion of missing data, analyses included 1946 children $(97.5 \%$ of respondents at 29 months). Tables 1 and 2 show distributions of child, maternal, and environmental characteristics.

A large proportion of mothers stated having experienced a lack of money for rent or mortgage (12\%), electricity or fuel to heat $(14 \%)$, clothing or transportation (13\%). Overall, about $10 \%$ of mothers had a score of 3 or more on the lack of money for basic needs variable indicating a serious lack of money (table 3).

As table 4 shows, $61.2 \%$ of children had had at least one acute health problem during the previous three months; $7.2 \%$ had had at least one asthma episode in the previous 12 months; $9.6 \%$ had a growth delay (under the 10th centile according to the $\mathrm{Z}$ scores on the CDC growth curve, $2000^{39}$ ); $11.2 \%$ of the children presented two or more health problems during the preceding year, and $7.6 \%$ had been hospitalised at least one night in the year preceding the survey. The most frequent reason for hospitalisation was respiratory problems, which may include asthma.
All indicators of child health were significantly linked to having a score of 3 or more on the scale for lack of money for basic needs (table 4). Those children from families with a serious lack of money for basic needs were more likely to be identified by the mother as having suffered an acute health problem, an asthma episode, a growth delay, or a combination of two or more of these problems compared with those children from families with no lack of money for basic needs. In addition, toddlers living in families with financial difficulties had greater odds of reporting a hospital admission in the previous 12 months. No gradient was observed.

Table 5 presents multivariate models of the relation between score for lack of money for basic needs and child health problems at 29 months. The odds for acute health problems, asthma episodes, and the index of health problems decreased slightly after controlling for the presence of health problems at 17 months and mothers' level of education, neonatal health problems, and child's age and sex. As expected, children for whom a health problem had been reported at 17 months had a greater probability of having this same problem at 29 months. However, living in a family with lack of money for basic needs increased the likelihood of having a reported new incidence of acute health problems, a growth delay problem, or cumulating two or more of these problems and possibly asthma episodes. The odds of reporting hospitalisations between 17 and 29 months for those having a lack of money to cover basic needs remained higher even after controlling for all confounding variables in the model. Results of analyses concerning child health status without controlling for health status at 17 months are essentially the same as those above. Odds ratios for lack of money were, however, slightly higher.

No multiplicative or additive interactions between mother's level of education and score for lack of money were observed for indicators of child health. Therefore, current

Table 5 Adjusted odds ratiost and $95 \%$ confidence intervals $(\mathrm{Cl})$ for the occurrence of new health problems in 2.5 year olds in Quebec longitudinal study of child development (QLSCD 1998-2002) according to the score for lack of money for basic needs

\begin{tabular}{|c|c|c|c|c|c|}
\hline & $\begin{array}{l}\text { Acute health problem } \\
\text { ( } n=1946) \\
\text { OR }(95 \% \mathrm{Cl})\end{array}$ & $\begin{array}{l}\text { Asthma episode } \\
\text { ( } n=1946) \\
\text { OR }(95 \% \mathrm{Cl})\end{array}$ & $\begin{array}{l}\text { Growth delay } \\
(n=1893) \\
\text { OR }(95 \% \mathrm{Cl})\end{array}$ & $\begin{array}{l}\text { Index of health } \\
\text { problems }=2 \text { or } 3 \S \\
(n=1893) \text { OR }(95 \% \mathrm{Cl})\end{array}$ & $\begin{array}{l}\text { Hospitalisation } \\
(\mathrm{n}=1946) \\
\text { OR }(95 \% \mathrm{Cl})\end{array}$ \\
\hline $\begin{array}{l}\text { Prior health } \\
\text { problem } \\
\text { Score for lack of } \\
\text { money }\end{array}$ & $2.3(1.9 \text { to } 2.8)^{\star * *}$ & $21.0(13.0 \text { to } 33.8)^{\star \star *}$ & $3.9(2.6 \text { to } 6.0)^{\star * *}$ & $5.4(3.6 \text { to } 7.9)^{* * *}$ & $4.1(2.8 \text { to } 6.0)^{* * *}$ \\
\hline Score $=0$ & 1 & 1 & 1 & 1 & 1 \\
\hline Score $=1-2$ & $1.1(0.8$ to 1.5$)$ & $1.1(0.6$ to 1.9$)$ & $1.1(0.7$ to 1.9$)$ & $1.2(0.8$ to 1.9$)$ & $1.3(0.8$ to 2.2$)$ \\
\hline Score $\geqslant 3$ & $1.7(1.1 \text { to } 2.8)^{*}$ & $1.7(0.9$ to 3.2$)$ & $1.9(1.1 \text { to } 3.3)^{*}$ & $2.0(1.1 \text { to } 3.3)^{*}$ & $2.4(1.3 \text { to } 4.4)^{* *}$ \\
\hline
\end{tabular}

${ }^{*} \mathrm{p}<0.05 ;{ }^{* *} \mathrm{p}<0.01 ;{ }^{* * *} \mathrm{p}<0.00$. †All models are adjusted for the previous health of the children at 17 months and the other variables: child's sex and age, small for gestational age, prematurity and congenital abnormality, type of child care, and mother's level of education. The model for asthma episode is also adjusted for mother's age and the presence of a pet in the house. The model for hospitalisation is also adjusted for mother's age. ‡The threshold for growth delay is established based on the value of 10th centile according to the Z score on the CDC growth curve, 2000. §The index of health problems (IHP) includes presence of 0-1 compared with two to three of the following problems: acute health problems, asthma episode, and growth delay. 


\section{Key points}

Lack of money for basic needs has a significant and unique impact on toddlers' health above and beyond the influence of maternal education and of neonatal health problems. Even in industrialised countries with universal medical care coverage, children's health can be negatively influenced by a lack of material resources.

data do not support the notion that lack of money for basic needs is more strongly associated with health effects among children of low educated women than among children of mothers with higher education. In other words, lack of money for basic needs is equally pervasive for all children regardless of mother's level of education.

\section{DISCUSSION}

Although many studies have shown a relation between low family socioeconomic status and children's health, the role of different dimensions of low socioeconomic status, and in particular of financial difficulties in the family, has not been thoroughly investigated. This study examined the unique contribution of serious financial difficulties, as measured by a lack of money for basic needs, on the occurrence of health problems in a representative birth cohort of children from Quebec aged between 1.5 and 2.5 years. Results showed that a high score for lack of money for basic needs is linked to occurrence of health problems in toddlers. Children raised in a family with a serious lack of money for basic needs during the preceding year are more likely to present acute health problems, a growth delay, or to cumulate two or more health problems, and to have been hospitalised for the first time within the past few months as compared with children living in a family that does not experience a lack of money for basic needs. This is true regardless of mother's level of education, age, marital status, immigration status, her health habits, and regardless of the child's neonatal health conditions. There is no gradient of poor health with increasing score for lack of money for basic needs suggesting that the effect is not attributable to occasionally having economic problems but rather to long term financial difficulties.

These results show that financial difficulties during early childhood have negative effects on the health of children and lead to the occurrence of new health problems in young children between the ages of 1.5 and 2.5 years. In a longitudinal analysis of the same cohort of children, longstanding poverty since birth had a negative impact on these health indicators including a first asthma episode between 17 and 29 months while current poverty had no effect. ${ }^{41}$ Cross sectional analyses may thus underestimate the real influence of poverty on children's health.

When mother's level of education is integrated into the models, there is little variation in the relation between score for lack of money and different indicators of health. Thus, mother's level of education does not confound the relation between financial difficulties reported by the mother and occurrence of toddler's health problems. Mother's education is not an effect modifier as financial difficulties have a similar effect on children's health regardless of mother's education. Family financial difficulties have a unique link with toddlers' health.

There are two main limitations of this study. Firstly, there is an absence of information on mother's social resources such as economic and emotional support from family and friends that would allow for testing of the hypothesis of a differential effect of lack of money for basic needs according to the availability of economic help to get out of a crisis.

\section{Policies implication}

Social and health policies must ensure that all families with a young child have sufficient income to care for their child.

Another limitation pertains to the self report nature of health indicators although literature suggests information on child health reported by the mother is valid. ${ }^{42}{ }^{43}$ Although there was no attempt to define asthma to respondents, the prevalence observed here is similar to prevalence observed in other studies suggesting that the measure did not over-report or under-report this health problem. The score for lack of money may also be a function of the mother's perception and could vary to her level of education. However, we did not observe any multiplicative, additive, or confounding effects with maternal education level. Lastly, a lack of statistical power is a possibility because the odds of having new asthma episodes became non-significant in the final multivariate model.

Among the study's strengths, we note that the sample is representative of $98 \%$ of singleton births in the province of Quebec. Furthermore, study follow up is excellent with minimal participant attrition. Finally, information is gathered through interviews conducted in participants' homes and several health indicators were analysed.

Data support the presence of a robust main effect of a lack of money for basic needs on young children's health. Thus, even in industrialised countries with universal medical care coverage and other wealth redistribution policies, children's health can be negatively influenced by lack of material resources: infant and child mortality thus seem more closely linked to “...families' capacity for meeting basic needs than to relative position within a state's economic hierarchy."23

A lack of material resources can affect children's health directly through under nutrition ${ }^{44}$ as well as through poverty elicited longstanding stress for both parents and children. ${ }^{46-48}$ The presence of more frequent health problems among poor children underscores the fact that the same children often present several health problems. This result suggests a greater overall vulnerability of poor children that may result from impairment of their immune system after long term stress. ${ }^{46} 48$

Prevention of health problems in poor children is critical because of the association between current health and adult health and cognitive function. ${ }^{49-53}$ Moreover, recent studies show the existence of links between growth delay among poor children and motor and cognitive development ${ }^{54-56}$ and cardiovascular disease in adulthood. ${ }^{57}$

Given these and other findings, ${ }^{13}{ }^{58-60}$ social policies must ensure that all families with a young child have sufficient income. Reducing inequalities in health among young children should be a public priority in Canada. ${ }^{61}$ Several Scandinavian and European countries such as Sweden, France, Belgium, and Great Britain have succeeded in reducing childhood poverty by "implementing family focused social policies." ${ }^{\prime 2}$ The utility for Canadian children of an alternative strategy that "...stresses the need for a coherent and efficient approach to human capital investment" has also been acknowledged. ${ }^{63}$ According to these authors, a diversified set of policies may be required and might include income support with measures such as universal child benefits graded according to age, work income credit, higher maternity leave and parental leave benefits, and maternity allowances and tax credit for child care expenses. In-kind transfers should also be offered such as full time public kindergarten for 4 and 5 year old children and early childhood interventions for infants and toddlers in at risk families. ${ }^{63}$ These findings and recommendations could guide 
policy makers interested in children's wellbeing. In the long term, reduction of social inequalities among children will benefit society as a whole.

\section{Authors' affiliations}

L Séguin, L Gauvin, M-V Zunzunegui, L Potvin, K L Frohlich, Department of Social and Preventive Medicine, University of Montreal, Canada L Séguin, Q Xu, L Gauvin, M-V Zunzunegui, L Potvin, K L Frohlich, Groupe de recherche interdisciplinaire en santé (GRIS)

Funding: this study was made possible through a research grant from the Canadian Institutes of Health Research (MOP-77835-PSB-CFCA32950).

Conflicts of interest: none declared.

Louise Potvin holds the CHSRF/CIHR Chair in Community Approaches and Health Inequality of the Canadian Health Services Research Foundation (CPI-0526-05) and Katherine L Frohlich was recipient of a post-doctoral fellowship from the Canadian Institutes of Health Research (765-2000-0054CHR1) during the preparation of this manuscript. The data collection was carried out by the Direction Santé Québec of the Institut de la statistique du Québec.

\section{REFERENCES}

1 Brooks-Gunn J, Duncan GJ. The effects of poverty on children. Future Child 1997;7:55-71

2 Aber JL, Bennett NG, Conley DC, et al. The effects of poverty on child health and development. Annu Rev Public Health 1997;18:463-83.

3 Roberts H. Socioeconomic determinants of health. Children, inequalities, and health. BMJ 1997;314:1122-5

4 Reading R. Poverty and the health of children and adolescents. Arch Dis Child 1997:76:463-7.

5 Huston AC, McLoyd VC, Coll CG. Children and poverty: issues in contemporary research. Child Dev 1994;65:275-82.

6 Montgomery LE, Kiely JL, Pappas G. The effects of poverty, race, and family structure on US children's health: data from the NHIS, 1978 through 1980 and 1989 through 1991. Am J Public Health 1996;86:1401-5.

7 Bor W, Najman JM, Andersen M, et al. Socioeconomic disadvantage and child morbidity: an Australian longitudinal study. Soc Sci Med 1993;36:1053-61.

8 Illi S, Von Mutius E, Lau S, et al. Early childhood infectious diseases and the development of asthma up to school age: a birth cohort study. BMJ 2001;322:390-5.

9 Spencer NJ, Coe C. Parent-reported infant health and illness in a whole year birth cohort. Child Care Health Dev 2000;26:489-500.

10 Newacheck PW, Halfon N. Prevalence, impact, and trends in childhood disability due to asthma. Arch Pediatr Adolesc Med 2000;154:287-93.

11 Newacheck PW. Poverty and childhood chronic illness. Arch Pediatr Adolesc Med 1994; 148:1143-9.

12 Ross DP, Roberts P. Income and child well-being : a new perspective on the poverty debate. Ottawa: Canadian Council on Social Development, 1999.

13 Alaimo K, Olson CM, Frongillo EA Jr, et al. Food insufficiency, family income, and health in US preschool and school-aged children. Am J Public Health 2001;91:781-6.

14 Casey PH, Szeto K, Lensing S, et al. Children in food-insufficient, low-income families: prevalence, health, and nutrition status. Arch Pediatr Adolesc Med 2001;155:508-14.

15 Chen E, Bloomberg GR, Fisher EB, et al. Predictors of repeat hospitalizations in children with asthma: the role of psychosocial and socioenvironmental factors. Health Psychol 2003;22:12-18.

16 Crain EF, Weiss KB, Bijur PE, et al. An estimate of the prevalence of asthma and wheezing among inner-city children. Pediatrics 1994;94:356-62.

17 Lewit E, Kerrebrock N. Population-based growth stunting. Future Child 1997:7:149-56.

18 Paradise JL, Rockette HE, Colborn DK, et al. Otitis media in 2253 Pittsburgharea infants: prevalence and risk factors during the first two years of life. Pediatrics 1997;99:318-33.

19 Böhm B, Katz-Salamon M, Smedler AC, et al. Developmental risks and protective factors for influencing cognitive outcome at $51 / 2$ years of age in very-low-birthweight children. Dev Med Child Neurol 2002;44:508-16.

20 Strauss RS, Dietz WH. Effects of intrauterine growth retardation in premature infants on early childhood growth. J Pediatr 1997;130:95-102.

21 Perlman JM. Neurobehavioral deficits in premature graduates of intensive care-potential medical and neonatal environmental risk factors. Pediatrics 2001; 108:1339-48

22 McGrath MM, Sullivan MC, Lester BM, et al. Longitudinal neurologic follow-up in neonatal intensive care unit survivors with various neonatal morbidities. Pediatrics 2000; 106:1397-405.

23 Hillemeier MM, Lynch J, Harper S, et al. Relative or absolute standards for child poverty: a state-level analysis of infant and child mortality. Am J Public Health 2003;93:652-57.

24 Chen J, Fair $M$, Wilkins $R$, et al. Niveau de scolarité et mortalité foetale et infantile au Québec. Rapports sur la santé 1998;10:57-70.
25 Cooper H, Arber S, Smaje C. Social class or deprivation? Structural factors and children's limiting longstanding illness in the 1990s. Sociology of Health and Illness 1998;20:289-311.

26 Gissler M, Rahkonen O, Järvelin MR, et al. Social class differences in health until the age of seven years among the Finnish 1987 birth cohort. Soc Sci Med 1998;46:1543-52.

27 Lynch JW, Davey Smith G, Kaplan GA, et al. Income inequality and mortality: importance to health of individual income, psychosocial environment, or material conditions. BMJ 2000;320:1200-4.

28 McCarthy PL, Christoffel KK, Dungy Cl, et al. Race/ethnicity, gender, socioeconomic status - Research exploring their effects on child health: a subject review. Pediatrics 2000;105:1349-51.

29 Marmot M, Wilkinson RG. Psychosocial and material pathways in the relation between income and health: a response to Lynch et al. BMJ 2001;322:1233-6.

30 Braveman P, Cubbin C. Optimal SES indicators cannot be prescribed across all outcomes. Am J Public Health 2003;93:12-13.

31 Daly MC, Duncan GJ, McDonough $P$, et al. Optimal indicators of socioeconomic status for health research. Am J Public Health 2002;92:1151-7

32 Daly MC, Duncan G, McDonough P, et al. Am J Public Health 2003;93:13.

33 Gazmararian JA, Adams MM, Pamuk ER. Associations between measures of socioeconomic status and maternal health behavior. Am J Prev Med 1996;12:108-15.

34 Chen J, Millar WJ. Birth outcome, the social environment and child health. Health Reports, Statistic Canada 1999:10:57-67.

35 Wilkins R. The health of children. Health Reports, Statistic Canada 1999;11.

36 Dubois L, Bédard B, Girard M, et al. "Diet" in Québec longitudinal study of child development in Québec (QLSCD 1998-2002). Vol 1. Québec: Institut de la statistique du Québec, 2000.

37 Dixon J, Macarov D. Poverty, a persistent global reality. London: Routledge, 1998.

38 Jetté M, DesGroseillers L. "Survey description and methodology" in Québec longitudinal study of child development (QLSCD 1998-2002). Vol 1. Québec: Institut de la statistique du Québec, 2000.

39 Ogden CL, Kuczmarski RJ, Flegal KM, et al. Centers for Disease Control and Prevention 2000 growth charts for the United States: improvements to the 1977 National Center for Health Statistics version. Pediatrics 2002; 109:45-60.

40 Reference withdrawn.

41 Séguin $L, X \cup Q$, Potvin L, et al. "Socioeconomic conditions and health, part 1 -poverty and health in Québecois children" in Québec longitudinal study of child development (QLSCD 1998-2002)-from birth to 29 months. Vol 2. Québec: Institut de la statistique du Québec, 2003.

42 Fields D, Draper ES, Gompels MJ, et al. Measuring later health status of high risk infants: randomised comparison of two simple methods of data collection. BMJ 2001;323:1-5

43 Bruijnzeels MA, Foets $M$, Van der Wouden JC, et al. Measuring morbidity of children in the community: a comparison of interview and diary data. Int J Epidemiol 1998;27:96-100.

44 Vozoris NT, Tarasuk VS. Household food insufficiency is associated with poorer health. J Nutr 2003;133:120-6.

45 Vozoris N, Davis B, Tarasuk V. The affordability of a nutritious diet for households on Welfare in Toronto. Can J Public Health 2002;93:36-40.

46 Lupien SJ, King S, Meaney MJ, et al. Child's stress hormone levels correlate with mother's socioeconomic status and depressive state. Biol Psychiatry 2000;48:976-80

47 Lupien SJ, King S, Meaney MJ, et al. Can poverty get under your skin? Basal cortisol levels and cognitive function in children from low and high socioeconomic status. Dev Psychopathol 2001;13:653-76.

48 Repetti RL, Taylor SE, Seeman TE. Risky families: family social environments and the mental and physical health of offspring. Psychol Bull 2002; 128:330-66.

49 Wadsworth M. Early life. In: Marmot M, Wilkinson RG, eds. Social determinants of health. New York: Oxford University Press, 1999:44-64.

50 Wamala SP, Lynch J, Kaplan GA. Women's exposure to early and later life socioeconomic disadvantage and coronary heart disease risk: the Stockholm female coronary risk study. Int J Epidemiol 2001;30:275-84.

51 Van de Mheen HD, Stronks K, Mackenbach JP. A lifecourse perspective on socio-economic inequalities in health: the influence of childhood socioeconomic conditions and selection processes. Sociology of Health and Illness 1998;20:754-77

52 Kuh D, Power C, Blane D, et al. Social pathways between childhood and adult health. In: Kuh D, Ben-Shlomo Y, eds. A life course approach to chronic disease epidemiology. Oxford: Oxford University Press, 1997.

53 Kaplan GA, Turrell G, Lynch JW, et al. Childhood socioeconomic position and cognitive function in adulthood. Int J Epidemiol 2001;30:256-63.

54 Cheung YB, Yip PSF, Karlberg JPE. Fetal growth, early postnatal growth and motor development in Pakistani infants. Int J Epidemiol 2001;30:66-74.

55 Richards M, Hardy R, Kuh D, et al. Birthweight, postnatal growth and cognitive function in a national UK birth cohort. Int J Epidemiol 2002;31:342-8.

56 Voss LD, Mulligan J, Betts PR. Short stature at school entry-an index of social deprivation? (The Wessex growth study). Child Care Health Dev 1998;24:145-56

57 Barker DJP, Forsén T, Uutela A, et al. Size at birth and resilience to effects of poor living conditions in adult life: longitudinal study. BMJ 2001;323:1-5.

58 Alaimo K, Olson CM, Frongillo EA Jr. Food insufficiency and American school-aged children's cognitive, academic, and psychosocial development Pediatrics 2001; 108:44-53. 
59 Dearing E, McCartney K, Taylor BA. Change in family income-to-needs matters more for children with less. Child Dev 2001;72:1779-93.

60 Garrett P, Ng'andu N, Ferron J. Poverty experiences of young children and the quality of their home environments. Child Dev 1994:65:331-45.
61 CCDS. Données de base sur la pauvreté au Canada-2000. Ottawa: Conseil canadien de développement social, 2000.

62 Roach JO. One in six children live in relative poverty. BMJ 2000;320:1621.

63 Lefebvre P, Merrigan P. Assessing family policy in Canada. A new deal for

families and children. Choices 2003;9:100.

POEM

\section{Tai Chi}

It relaxes the body

It's good for the soul

It releases tension

for the young and the old

Movements that keep you healthy

they call it the art of TAI CHI

It exercises the limbs all over

It purifies the blood

makes you healthier

Stretching, turning rhythmically

flowing, moving consciously

Relaxed movements

like the sea flows

controlled breathing

like the wind blows

A ancient art

from civilized nation

A series of moves

in deep meditation

The yin and the yan

which is soft and hard

you can only comprehend it

if your mind is broad

It functions to the beat

of creation

It balances left and right

in perfection

So why not make friends with your body?

Through the art of TAI CHI.

\section{ACKNOWLEDGEMENTS}

This poem was originally published in Tafari L. Rhyme Don't Pay. Wirral, UK: Headland Publications, 1993 (available from Headland Publications at 38 York Avenue, West Kirby, Wirral CH48 3JF), and is reproduced in the JECH with the author's permission.

Levi Tafari

levi@tafari.freeserve.co.uk 